\section{Med foreldre i krigen}

Barn over tre år blir påvirket av at en av foreldrene er utstasjonert i en krigssone. Det viser en studie av militærfamilier (Arch Pediatr Adolesc Med 2008; 162: 1009-14).

Forskerne undersøkte effekten på barnas oppførsel av at en av foreldrene ble sendt ut i krig. 169 familier med barn i barnehager på militærbaser deltok i studien. 55 av barna (33\%) hadde en foresatt som deltok i militære aktiviteter.

Barn over tre år der en av foreldrene var $i$ en krigssone hadde signifikant høyere depresjonsskår enn barn i andre familier. Det var ingen demografiske forskjeller mellom gruppene. Forskjellene i depresjonsskår sto seg også etter at forskerne kontrollerte for symptomer på stress og depresjon hos foreldrene.

\section{Statiner og myopati}

Ulike muskelsykdommer, som myalgi, myositt, rabdomyolyse og asymptomatisk $ø k t$ kreatinkinase, er assosiert med statinbruk. Engelske forskere har nå oppsummert epidemiologiske og randomiserte studier om statinindusert myopati $i$ en oversiktsartikkel (BMJ 2008; 337, a2286).

Statinindusert myopati korrelerer best med statindose, men faktorer som øker serumkonsentrasjonen av statin kan øke risikoen. Dessuten vil lipofile statiner lettere trenge inn i muskelvev enn hydrofile, med økt mulighet for myotoksiske effekter. I tillegg til at alder, kjønn, kroppsmasseindeks, visse andre sykdommer og livsstilsfaktorer kan ha betydning for myopatirisikoen kan også genetiske faktorer spille en rolle.

Selv om andelen statinbrukere som får myopati er lav, vil det økte forbruket av statiner føre til et betydelig antall pasienter med slike lidelser.

\section{DNA-sekvensen}

\section{til malariaparasitter}

Den humane malariaparasitten Plasmodium vivax er ansvarlig for $25-40 \%$ av malariatilfellene i verden. Parasitten er lite studert pga. vanskeligheter med å dyrke den i laboratorier. Man er i økende grad blitt klar over at også Plasmodium knowlesi kan forårsake malaria hos mennesker. To forskningsgrupper har nå sekvensert genomet til disse parasittene (Nature 2008; 455: 757-63, 799-84).

Ved å studere sekvensen kunne forskerne avsløre at genomet liknet andre malariaparasitter i geninnhold, men $i$ tillegg ble det funnet nye genfamilier og potensielle alternative invasjonsveier. Kunnskapen om DNA-sekvensen bidrar til å øke forståelsen av de fenotypiske forskjellene mellom de ulike plasmodiumartene, mener forskerne.

\title{
Psykologisk behandling ved diabetes
}

\author{
Kognitiv terapi i tillegg til motiva- \\ sjonsforbedrende tiltak og standard- \\ behandling kan gi lettgradig reduk- \\ sjon av $\mathrm{HbA}_{1 \mathrm{C}}$-nivået.
}

I en engelsk studie fulgte man opp 344 pasienter med type 1-diabetes over 12 måneder (1). Ved inklusjonstidspunktet hadde alle hatt diabetes i mer enn to år, moderat forhøyede $\mathrm{HbA}_{1 \mathrm{c}}$-verdier og ingen alvorlige komplikasjoner. Alle deltakerne fikk standardbehandling. Halvparten fikk dessuten et motivasjonsforbedrende opplegg med og uten tillegg av kognitiv terapi fordelt over 16 sesjoner. Den psykologiske behandlingen ble gitt av sykepleier.

Gruppen som fikk motivasjonsforbedrende samtaler pluss kognitiv terapi hadde $0,46 \%$ større $\mathrm{HbA}_{1 \mathrm{c}}$-reduksjon enn dem som kun fikk standardbehandling. Behandlingen ga imidlertid ingen forskjell mellom gruppene i forekomst av depresjon, livskvalitet, kroppsmasseindeks eller andre av de sekundære endepunkter.

- I en tid med mye oppmerksomhet omkring nye insulintyper som skal være bedre enn de tradisjonelle for å regulere blodsukkeret, peker denne studien på viktigheten av motivasjon og psykologisk interaksjon mellom behandler og pasient, sier professor Kåre Birkeland ved Endokrinologisk senter, Aker universitetssykehus.

- Det er interessant at motiverende samtaler annenhver uke $\mathrm{i}$ to måneder ikke hadde dokumenterbar effekt, mens det å benytte teknikker fra kognitiv terapi over fire ekstra måneder i tillegg ga signifikant bedring av $\mathrm{HbA}_{1 c}$-nivået. Likevel må man si at effekten på gjennomsnittlig $\mathrm{HbA}_{1 c^{-}}$ nivå var moderat. Det ville vært interessant å se effekten hos dem som virkelig hadde dårlig blodsukkerkontroll, det vil si $\mathrm{HbA}_{1 c^{-}}$ nivå over $10 \%$, sier Birkeland.

\section{Are Brean}

are.brean@siv.no

Tidsskriftet

\section{Litteratur \\ 1. Ismail K, Thomas SM, Maissi E et al. Motivational enhancement therapy with and without cognitive behavior therapy to treat type 1 diabetes: a rando- mized trial. Ann Intern Med 2008; 149: 708-19.}

\section{Acetylsalisylsyre og antioksidanter ved diabetes?}

\section{Antioksidanter har ingen effekt på utvikling av kardiovaskulær sykdom og død ved diabetes.}

Acetylsalisylsyre har effekt som sekundærprofylakse mot kardiovaskulære hendelser, men det er ikke dokumentert at antioksidanter har det. Nå har forskere undersøkt effekten av acetylsalisylsyre og antioksidanter på utvikling av hjerte- og karsykdom hos pasienter med diabetes og asymptomatisk perifer karsykdom (1).

En randomisert multisenterstudie omfattet 1276 personer over 40 år med type 1- eller type 2-diabetes og med ankel-armindeks $\leq 0,99$, men uten symptomer på hjerte- og karsykdom. Gruppene fikk daglig hhv. $100 \mathrm{mg}$ acetylsalisylsyre, en antioksidantkapsel, kombinasjonen av disse og placebomedisin. Median oppfølgingstid var 6,7 år. Resultatene ga ingen støtte til bruk av acetylsalisylsyre eller antioksidanter, verken hver for seg eller i kombinasjon.

- Studien viser at antioksidantsupplement ikke gir redusert insidens av kardiovaskulær sykdom ved diabetes, men den gir ikke noen endelig avklaring på om primærprofylakse med acetylsalisylsyre gjør det, sier lege Odd Erik Johansen ved Sykehuset Asker og Bærum.
- Studien var for liten til å avklare hvilken plass acetylsalisylsyre skal ha i diabetesbehandlingen. Mangel på styrke var trolig årsak til at det heller ikke ble påvist nytte for subgrupper. En signifikant gevinst ved alder over 65 år ble nylig vist $i$ en noe større studie (2). Dagens retningslinjer, som anbefaler acetylsalisylsyre til pasienter med minst én tilleggsrisikofaktor, bør derfor ikke endres. Opptil en av fem personer med type 2-diabetes, og kanskje enda flere ved type 1-diabetes, kan ha stum signifikant koronarsykdom. Disse skal håndteres etter prinsippene om sekundærprofylakse, sier Johansen.

\section{Trine B. Haugen}

trine.b.haugen@hf.hio.no

Tidsskriftet

\section{Litteratur}

. Belch J, MacCuish A, Campbell I et al. The preven tion of progression of arterial disease and diabetes (POPADAD) trial: factorial randomised placebo controlled trial of aspirin and antioxidants in patients with diabetes and asymptomatic peripheral arterial disease. BMJ 2008; 337: a1840. 2. Ogawa H, Nakayama M, Morimoto T et al. Lowdose aspirin for primary prevention of atherosclerotic events in patients with type 2 diabetes: a randomized controlled trial. JAMA 2008; 300: $2134-41$ 